\title{
FEEDING PATTERN, HORMONAL OXIDATIVE BALANCE AND LIVER EXPECTANCY
}

\author{
Ali I S Ahmed; Abdel Monhim S Hashish; Salwa S Gabal and Neveen A Elwardany* \\ Special Food and Nutrition Dept. Food Technology Research Institute, ARC. *Fac. Specific \\ Edu. Alex. Univ.
}

\begin{abstract}
One of the most clinical assignments affecting human being in the present time is liver defect. Therefore, several factors that known to positively or negatively dealt with this organ were investigated in the present study. A 60 rats have been divided into four groups (3x6, 2x6, 3x6 and 2x6) of ten specific subgroups as follows: The control groups fed on basal diet (G1); G2 is a high fat diet HFD containing 20\% animal fat or same with $5 \%$ of doum waste powder (HFD+DW) as G3; G4 is tetra cholro carbon (TCC) and G5 is alike received grape laves extract. In G6 animal received TPN solution, while G7 treated the same pluse lasix as duritic synthetic druge and G8 replcinng this drug with natural one. In G9 diet was contamented with afflatoxin, meanwhile, G10 was similar but a rich protein antioxidant was subleminted. It seems that the liver homeorhestic function, i.e., cortisone to insulin is governed by its homeostatic control of organ, or vice versa, hence dismutase SOD, catalase, were sharply reduced and each of GOT, GPT or AP enzymes increased with food contaminated or artificial drug administration concurantly to a sort of hormonal imbalanc. Significat repairment were noticed for feeding systemes used. These findings have been approved by organ microscopically tests. The

DW, for instance, successfully decreases the influances of HFD. There were also evidence of the hepatotoxicity of TCC and of the hepatoprotective effect of the extract of grape leave juces. The minimal or maximal disruptions of the hepatocyte structure are complemented the liver enzyme data of GOT, GPT and ALP activities and other biological parameters. In case of TPN histopathology, liver of rat treated with TPN of mixed natural extract minamized the effect of TPN alone. Likewise, the microscopical examination of liver of rat with diet contaminated of micotoxin, a highly protection for a high proteinantioxidant (HPAO) formula arises. Seemingly, feeding pattern affects hormonal oxidative balanc to perform better liver expectancy. In general conclusion, feeding pattern should be developed to help in protecting human liver, especially in poor areas allover the world. Very simple foods or even food wastes is considered hepatoprotective agents. The hormonal oxidative balance has to be further investigated in order to produce such important food that may protect liver worldwide.
\end{abstract}

\section{INTRODUCTION}

Liver is subjected to the human most dangerous defects nowadays. Blood composition always reflects liver status. Serum selenium, for instance, was evaluated in relation to hepatic structure and function according to hepatic histology. Serum selenium level was related to the severity of liver disease, and most reduced in subjects with decompensate alcoholic cirrhosis. Their serum selenium level was below that obtained in alcoholics with normal liver and fatty liver, respectively. Both inadequate dietary selenium intake and alcohol-induced changes in hepatic structure and function may have contributed to the decrease of serum selenium in the subjects studied (Korpela, et al., 1985). In digestive and liver diseases, nonalcoholic steatohepatitis (NASH) affects 3-5\% of the general adult population and predisposes to cirrhosis, cardiovascular disease (CVD), and diabetes through unclear mechanisms. Lectin-like oxidized LDL receptor-1 (LOX-1) has been connected to CVD risk in the general population and to insulin resistance and hepatic 
fibrogenesis in experimental models by affecting both insulin secretion and insulin sensitivity (Musso, et al., 2011). Moreover, although nonalcoholic fatty liver disease (NAFLD) is associated with the metabolic syndrome, the mechanisms responsible for the development of NAFLD at different stages of the development of insulin resistance are unknown. Diet, adipokines, and nitrosative stress have been linked to both NAFLD and insulin resistance. However, oxidative stress is operating in NAFLD and nonalcoholic steatohepatitis, even in the absence of insulin resistance, the metabolic syndrome, and hypoadiponectinemia, which aggravate liver histology at more severe stages of metabolic disease. Moreover, the possible pathogenesis role of reduced vitamin A intake in NAFLD warrants further investigation (Musso, et al., 2007). Likewise, betaine and folate in the treatment of alcoholic liver disease (ALD), supplementation may attenuate ALD by decreasing oxidative stress through the up-regulation of glutathione synthesis, reducing inflammation via the down-regulation of tumor necrosis factor- $\alpha$ and the up-regulation of interleukin-10 synthesis, inhibiting the apoptosis of normal hepatocytes and stimulating the apoptosis of liver cancer cells. Folate deficiency may accelerate or promote ALD by increasing hepatic homocysteine and; decreasing hepatic glutathione concentrations and increasing cytochrome P4502E1 activation and lipid peroxidation; up-regulating endoplasmic reticulum stress markers, including sterol regulatory element-binding protein1, and proapoptotic gene caspase-12; and decreasing global DNA methylation. Betaine may attenuate ALD by decreasing the hepatic concentrations of homocysteine and, which can trigger a cascade of events that lead to the activation of phosphatidylethanolamine methyltransferase, increased phosphatidylcholine synthesis, and formation of VLDL for the export of triacylglycerol from the liver to the circulation. Additionally, decreased concentrations of homocysteine can down-regulate endoplasmic reticulum stress, which leads to the attenuation of apoptosis and fatty acid synthesis (Purohit, et al., 2007). NAFLD is a significant health problem and affects 70 million adults in the United States, and an estimated $20 \%$ of these individuals have the most severe form of NAFLD — nonalcoholic steatohepatitis (NASH). The mechanisms underlying disease development and progression are awaiting clarification. Insulin resistance and obesity-related inflammation, among other possible genetic, dietary, and lifestyle factors, are thought to play a key role. The effects of macronutrient content and specific food components and issues related to current dietary guidelines and specific diets were discussed (Zivkovic, et al., 2007). Concerning vitamins, minerals, and phytochemicals, infants may regulate copper absorption and the potential effects of excess copper in early life remain poorly defined. When the animals were 1, 5, and 8 mos old, liver copper and metallothionein concentrations, liver histology and the number of Küpffer cells were assessed, and ${ }^{67} \mathrm{Cu}$ retention was measured in this study. Liver function was assessed by measurement of plasma alanine aminotransferase, aspartate aminotransferase, gamma-glutamyl transferase, and alkaline phosphatase activities and protein, albumin, bilirubin, and blood urea nitrogen concentrations. Copper absorption was down-regulated; increases in liver copper content at ages 1 and 5 mo did not result in histologic damage. Ultrastructural changes at age 5 mos could signal early cellular damage (Araya, et al., 2005). On the other hand, relation of digestion and liver diseases imposed a significant histologic and biochemical overlap between NAFLD and steatohepatitis associated with choline deficiency. It is sought to determine whether subjects with biopsyproven NAFLD and evidence of an inadequate intake of choline had more severe histologic features. Decreased choline intake is significantly associated with increased fibrosis in postmenopausal women with NAFLD. The Pioglitazone vs. Vitamin E vs. P placebo for treatment of non-diabetic patients with nonalcoholic steatohepatitis trial was registered at clinical trials (Guerrerio, et al., 2012). Regarding obesity and eating disorders, weight loss was shown to be associated with improvements in liver enzymes and improvements of nonalcoholic fatty liver disease. However, some evidence also shows that liver enzymes may 
transiently increase immediately after a dietary-induced weight loss (Gasteyger, et al., 2008). Unfortunately CHD associates deleterious metabolic effects of visceral fat deposition and liver fat emerged as having a key independent role in the modulation of cardiometabolic risk factors. Liver fat accretion may play a role in the ethnic differences seen in large VLDL particles (D'Adamo et al., 2010). Several simple food pattern protect liver againest seriouse diseases. Doum palm (Hyphaene thebaica), for instance, is a fruit that has nutritional and pharmacologic properties, as increasing circulation of fatty acids associates rising lipolysis in adipocytes with insulin resistance, results in a plethora of fatty acids to non-adipose tissues such as muscle, pancreas and liver. This work is giving some example about ways that may used to facilitats liver expectancy.

\section{MATERIAL AND METHODS}

Material: The dried fruit waste (G1- G3) of doum powder and preparation of grape leave water extract (G4 and 5) were follwoed that procedures used by Bayomey et al. (2010) and Gaafar et al. (2010), respectively. Meanwhile, TPN technique (G6-8) and rich protein antioxidant formula (G 9 and 10) employed were according to those used by Ahmed $\boldsymbol{e t}$ al. (2008) and Abo-Zeid et al. (2008) in the same respect.

Animals and diets: Adult aged male albino strain rats were obtained from Research Institute of Ophthalnmalogy, Giza, Egypt. The 60 (3x6, 2x6, 3x6 and 2x6) rats as arranged in the four upmentioned exeperment had been conducted for 10 days of adaption on a basal diet according to FAO/WHO (1974) to around $385 \mathrm{~g} \pm 5$ grams (age of 4 month) befor starting the trails. The rats were divided into these four groups then their specific subgrouping as follow:

1- The control groups fed on basal diet as group 1 negative control (G1), high fat diet containing 20\% animal fat (positive control) G2 and treatment group fed on the high fat diet with $5 \%$ of doum waste powder G3.

2- Group 4, toxin control tetra cholro carbon (TCC) (50\% solution of TCC, G5 was same received grape laves extract $(0.2 \mathrm{~g} / \mathrm{kg} \mathrm{BW})$.

3- G6 received TPN solution, while G7 treated the same pluse lasix as duritic synthetic druge (Ahmed et al., (2008) and G8, replcinng this drug with natural one.

4- In G9, afflatoxin was added to basel diet (Abo-Zeid et al., (2008), meanwhile, G10 was similar but a rich protein antioxidant was subleminted. At the end of $2 \mathrm{wk}$, rats were sacrificed by decapitation after blood samples were collected from the inferior vena cava. The serum was separated from the blood, and the serum and liver was removed and stored at $-20{ }^{\circ} \mathrm{C}$ until analysis. rats livers were dissected out and weighed, then kept in formalin $10 \%$ for histopathological study.

In the determination of hormones: Insulin in serum was determined according to the method developed by Ahmed $\boldsymbol{e t}$ al. (2006). Likewise, estrogen (cortisone) was adapted to that of Ahmed et al. (2001). Area under the peak ratio for similar solute preparation with injection fixed volume was taken for the two hormones making that of control group as unity.

In case of enzymes determination, the mean reduced glutathione concentration ( $\mu$ mol glutathione/mg protein) in the liver homogenate was determined by the method of Moron $\boldsymbol{e t}$ al. (1979). The enzyme activities of catalase (CAT) was assayed by the method of Sinha (1972) and superoxide dismutase (SOD) was determined by the method of Marklund and Marklund (1974), meanwhile, a colorimetric method was used in determination of serum glutamic oxaloacetic, glutamic pyruvic transaminase and alkalin phosphatase (Bergmeyer and Harder, 1986). 
Histopathology: The histopathological examination was carried out on the liver of all groups in department of pathology, college of veterinary medicine, Cairo university. At the end of the biological experiments, the rats were scarified, and the liver was embedded in paraffin wax then sectiond at the thickness of 5-6 $\mu$ and stained in hoematoxylin and eosin mixture according to Frankel and Reitman, (1963).

Statistical analysis: The LSD was used to compare the main differences between treatments. Percentages were transformed to the arcsine. The arcsine percentages were subjected to the proper analysis of variance (Snedecor and Cochran, 1967).

\section{RESULTS AND DISCUSSION}

Liver is strongly affected by consuming good or bad nutritionaly diets. In Table 1, rat's liver metabolic parameters have shown remarkable changes, i.e. both level of hormons or enzymes. However, Stull and Rodiek (1988) in two experiments conducted to determine the response of blood glucose, insulin and cortisol levels to four common equine diets reported that analysis of variance by repeated measures and mean response area for insulin showed differences between diets. Cortisol showed no meal-related responses to any of the diets. Contrary, this hormone was highly responed in case such as toxification with either TCC or afflatoxin. Hormonal imbalance may be caused by some drugs (see the same Table). De Prior et al., (1980) have stated that glucocorticoids, depending upon their chemical structure, may produce opposite changes in membrane insulin binding sites. Furthermore, since dexamethasone and cortisone affect plasma insulin levels in the same fashion as previously reported with prednisone, it is suggested that the variation in insulin binding observed after glucocorticoids treatment is not due to variations in insulinemia.

Table (1) Effect of some feeding pattern on hormonal and oxidative balance and liver enzymes in rats.

\begin{tabular}{|c|c|c|c|c|c|c|c|c|}
\hline G & $\begin{array}{l}\text { Sub } \\
\text { G }\end{array}$ & Diets & $\begin{array}{l}\text { Cort } \\
\text { :Ins }\end{array}$ & $\begin{array}{l}\text { Dismuta } \\
\text { se SOD }\end{array}$ & Catalase & GOT & GPT & $\overline{\mathbf{A P}}$ \\
\hline 1 & $1-1$ & Normal & 1.00 & $\begin{array}{c}6.35^{\mathrm{a}} \pm \\
0.356 \\
\end{array}$ & $\begin{array}{c}81.56^{\mathrm{a}} \pm \\
6.65\end{array}$ & $\begin{array}{c}66.4^{\mathrm{d}} \pm \\
51\end{array}$ & $\begin{array}{c}32.23^{c} \pm 3 \\
1\end{array}$ & $\begin{array}{c}121.5^{c} \pm \\
61\end{array}$ \\
\hline 1 & $1-2$ & High fat diet HFD & 1.36 & $\begin{array}{l}3.37^{\mathrm{c}} \pm \\
0.244\end{array}$ & $\begin{array}{c}41.58^{\mathrm{c}} \pm \\
2.87\end{array}$ & $\begin{array}{c}196.3^{\mathrm{a}} \\
\pm 39\end{array}$ & $\begin{array}{c}121.3^{\mathrm{a}} \pm \\
72\end{array}$ & $\begin{array}{c}288.5^{\mathrm{a}} \pm \\
54\end{array}$ \\
\hline 1 & $1-3$ & $\begin{array}{l}\text { HFD+doum waste } \\
\text { powder }\end{array}$ & 1.11 & $\begin{array}{l}5.55^{\mathrm{b}} \pm \\
0.412\end{array}$ & $\begin{array}{c}56.11^{\mathrm{a}} \pm \\
4.52\end{array}$ & $\begin{array}{c}106.7^{b} \\
\pm 69\end{array}$ & $\begin{array}{c}61.44^{b} \pm \\
54\end{array}$ & $\begin{array}{c}142.6^{b} \pm \\
94\end{array}$ \\
\hline 2 & $2-4$ & Toxin control TCC & 1.38 & $\begin{array}{l}3.17^{\mathrm{c}} \pm \\
\mathbf{0 . 2 1 7}\end{array}$ & $\begin{array}{c}43.28^{\mathrm{c}} \pm \\
5.12\end{array}$ & $\begin{array}{c}188.3^{\mathrm{a}} \\
\pm 93\end{array}$ & $\begin{array}{c}101.3^{\mathrm{a}} \pm \\
72\end{array}$ & $\begin{array}{c}276.5^{\mathrm{a}} \pm \\
35\end{array}$ \\
\hline 2 & $2-5$ & $\begin{array}{l}\text { TCC + grape laves } \\
\text { extract }\end{array}$ & 1.13 & $\begin{array}{l}5.34^{\mathrm{b}} \pm \\
0.254 \\
\end{array}$ & $\begin{array}{c}76.63^{\mathrm{a}} \pm \\
5.84 \\
\end{array}$ & $\begin{array}{c}98.5^{\mathrm{c}} \pm \\
54\end{array}$ & $\begin{array}{c}\mathbf{6 6 . 2 4}^{\mathrm{b}} \pm \\
57\end{array}$ & $\begin{array}{c}1^{141.6^{b c}} \pm \\
77\end{array}$ \\
\hline 3 & $3-6$ & TPN solution & 1.27 & $\begin{array}{l}4.64^{b} \pm \\
0.422\end{array}$ & $\begin{array}{c}65.56^{\mathrm{a}} \pm \\
3.46 \\
\end{array}$ & $\begin{array}{c}93.8^{\mathrm{c}} \pm \\
52 \\
\end{array}$ & $\begin{array}{c}61.54^{b} \pm \\
93 \\
\end{array}$ & $\begin{array}{c}135.6^{\mathrm{bc}} \pm \\
91\end{array}$ \\
\hline 3 & $3-7$ & $\begin{array}{l}\text { TPN+ lasex as duritic } \\
\text { synthetic druge }\end{array}$ & 1.47 & $\begin{array}{l}2.99^{\mathrm{d}} \pm \\
0.401\end{array}$ & $\begin{array}{c}43.84^{\mathrm{d}} \pm \\
4.98\end{array}$ & $\begin{array}{c}289.5^{\mathrm{a}} \\
\pm 48\end{array}$ & $\begin{array}{c}101.68^{\mathrm{a}} \pm \\
13\end{array}$ & $\begin{array}{c}311.3^{\mathrm{a}} \pm \\
55\end{array}$ \\
\hline 3 & $3-8$ & $\begin{array}{l}\text { TPN+ natural duritic } \\
\text { one. }\end{array}$ & 1.02 & $\begin{array}{c}5.47^{\mathrm{b}} \pm \\
0.418\end{array}$ & $\begin{array}{c}43.28^{c} \pm \\
5.12\end{array}$ & $\begin{array}{c}88.6^{c} \pm \\
75\end{array}$ & $\begin{array}{c}48.49^{b} \pm \\
48\end{array}$ & $\begin{array}{c}135.6^{b c} \pm \\
91\end{array}$ \\
\hline 4 & $4-9$ & Afflatoxin (AFF) & 1.49 & $\begin{array}{l}3.21^{\mathrm{c}} \pm \\
0.405\end{array}$ & $\begin{array}{c}3^{33.24^{b}} \pm \\
3.99\end{array}$ & $\begin{array}{c}278.3^{\mathrm{a}} \\
\pm 82 \\
\end{array}$ & $\begin{array}{c}109.18^{\mathrm{a}} \pm \\
51\end{array}$ & $\begin{array}{c}321.6^{\mathrm{a}} \pm \\
95\end{array}$ \\
\hline 4 & $4-10$ & $\begin{array}{l}\text { AFF+rich protein } \\
\text { antioxidant }\end{array}$ & 1.04 & $\begin{array}{l}5.70^{b} \pm \\
0.312 \\
\end{array}$ & $\begin{array}{c}78.69^{a} \pm \\
8.54\end{array}$ & $\begin{array}{c}144.9^{\mathrm{a}} \\
\pm 12 \\
\end{array}$ & $\begin{array}{c}81.33^{\mathrm{a}} \pm \\
32\end{array}$ & $\begin{array}{c}136.5^{\mathrm{a}} \pm \\
36\end{array}$ \\
\hline
\end{tabular}

G, animal group. Cort:Ins, Cortisone/Insulin ratio. GOT, glutamyl oxalacetate transaminase. GPT, glutamyl pyruvate transaminase. AP, alkaline phosphatase in IU/ML. Values are expressed as mean 
\pm SD of six rats in each group. CAT: Catalase CAT $-1 \mathrm{~mol}$ of $\mathrm{H} 2 \mathrm{O} 2$ utilized/min $/ \mathrm{mg}$ protein. SOD: Superoxide dismutase - Unit/mg protein. $* \mathrm{P}<0.05$ (ANOVA) not significant at $5 \%$ level.

The homeorhestic role of liver function seems to be governed by its homeostatic control of organ or actully vise versa. All of dismutase SOD, catalase, GOT, GPT or AP enzymes were also changed according to factors mentioned here. For example, Munnich $\boldsymbol{e t}$ al. (1984) using a cDNA probe complementary to rat L-type pyruvate kinase mRNAs showed that three conditions are required for the synthesis of liver L-type pyruvate kinase mRNAs: (i) the presence of dietary carbohydrates, (ii) the cessation of glucagon release, and (iii) the presence of permissive hormones, including insulin. In human, Castellanos and Arroyave (1961) biologically investigated six children with kwashiorkor upon admission were found to excrete significantly less 17-hydroxysteroids than five with marasmus although the 17-ketosteroid excretion was not significantly different in the two groups. Cortisone caused a marked increase in serum albumin and liver protein and a decrease in liver fat but with the other treatments these effects were not noticed. A marked degree of muscle wasting has been demonstrated histologically and chemically in the groups given cortisone. None of the treatments caused any change in the results of the measurements in well nourished rats. Thus, the child with marasmus resembled the protein-deficient rat given cortisone while the child with kwashiorkor was similar in several basic ways to proteindeficient rats given sodium chloride. When casein administrated as drug, a clear metabolic role can be measured, Hausberger (1958) earlier in a rat experiment received $2.5 \mathrm{mg}$ and 5 $\mathrm{mg}$ of cortisone acetate and/or various amounts of protamine zinc insulin for 4 and 14 days, respectively, found that insulin produced markedly accelerated oxidation of, and lipogenesis from, radio glucose by surviving liver and adipose tissue. Pre-treatment with cortisone diminished oxidation and lipogenesis in both tissues. After simultaneous administration of both hormones, the insulin effect was the prevailing one. Insulin stimulated adipose tissue metabolism in vitro to the same degree as after administration in vivo. It is theorized that the adiposity seen in hyperadrenocorticism may be caused by the prevailing effect of insulin on adipose tissue growth and adipose tissue lipogenesis. In an earlier, communication it was shown that insulin administration accelerates fat deposition in, and growth of, adipose tissue. This effect is only moderately and inconsistently diminished by simultaneous cortisone injections. Likewise, the interactions between insulin, cortisone and thyroxin on the functional maturation of the small intestine of 8-day-old suckling mice have been estimated and animals received one injection/day during 3 days of a single hormone or of the following hormonal combinations: insulin plus cortisone or insulin plus thyroxin as well. It appeared that insulin, cortisone and thyroxin have their own specific effect on differentiation and proliferation of the epithelial cells and that these three hormones act in cooperation to induce the maturation of the suckling mouse small intestine during postnatal development (Ménard, 1983).

Still hormonal balance controlled in most cases with feeding pattern and influence cell proliferation and health even in old age cycle as existed in the present study. The following Tables and figures illustrated the effect of above mentioned feeding effectors on rat liver tissues. Liver function parameters may conformed by the histopathological examination shown in figures from 1 to 5 and these liver diorders also are summerized in Tables from 2 to 5. Microscopically, liver of rat fed 5\% doum waste poweder revealed no histopathological changes except some sections revealed congestion of central veins, whereas liver of rat from high fat diet group revealed vacillations of hepatocytes, sinusoidal leucocytosis and local hepatic necrosis associated leucocytic cells infiltration. On the other hand, histopathological studies performed to provide direct evidence of the hepatotoxicity of TCC and of the hepatoprotective effect of the extract of grape leave appear to had marked disruption of the structure of hepatocytes liver tissue of rats exposed to toxin alone, i.e. only minimal disruption of the structure of hepatocytes was noticed in liver tissue of group when 
rats exposed to TCC and grape water extract. In harmony, Orhan et al. (2007) have detected a hepatoprotective effect of Vitis vinifera L. leaves on carbon tetrachloride-induced acute liver damage in rats. These minimal or maximal disruptions of the hepatocyte structure are complemented the liver enzyme data of GOT, GPT and ALP activities or other biological parameters as well as deviation in hormonal balance. In case of TPN histopathology, liver of rat treated with TPN alon (Tabie 4 and figure 4) showed local mononuclear inflammatory cells infiltration and vaculations of hepatocytes. Improvement in the liver was observed in the group treated with TPN + parsley + green tea as the liver appeared with apparent normal hepatocytes. However, liver of rat treated with TPN and lasix showed hemolysed RBCs and deposition of golden brown hemosidrine pigment as well as necrosis epatocytes with pyknosis of their nuclei.

Table (2): Histopathological architecture in the liver of rats with high fat or plus AO in doum waste powder (DWP).

\begin{tabular}{|l|l|l|l|}
\hline Histopathological remarks & NC & HFD & $\begin{array}{l}\text { HFD } \\
\text { +DWP }\end{array}$ \\
\hline No histological changes & + & & \\
\hline Vacuolation of hepatocytes. & & + & \\
\hline Sinusoidal leucocytosis. & & + & \\
\hline Focal hepatic necrosis assoiceted with leucocytic cells infiltration. & & + & \\
\hline Slight dilatation of hepatic sinusoids. & & + & + \\
\hline Necrosis of sporadic hepatocytes. & & & + \\
\hline
\end{tabular}

Table (3): Histopathological summary of TCC and TCC+ grape extract (E) effect on rat liver.

\begin{tabular}{|l|l|l|}
\hline Histopathological remarks & TCC & TCC+E \\
\hline Marked disruption of the structure of hepatocytes & + & \\
\hline Marked disruption of the structure of hepatocytes & & + \\
\hline Lucocytic cells & + & \\
\hline Hepatocytes cytomegaly nuclai & + & \\
\hline Hepatocytes karyomegly nuclai & + & \\
\hline Granular degeneration of heatocytes & + & \\
\hline
\end{tabular}

Table (4): Histopathological architecture in the Liver of TPN, + drug and +NEX experimental Rats.

\begin{tabular}{|l|l|l|l|}
\hline Histopathological remarks & TPN & +DRUG & +NEX \\
\hline local mononuclear inflammatory cells infiltration. & + & & \\
\hline Vaculations of hepatocytes. & + & & \\
\hline Normal hepatocytes. & & & + \\
\hline Hemolysed RBcs. & & + & \\
\hline deposition of golden brown hemosidrine pigment & & + & \\
\hline Necrosis of hepatocytes with pyknosis of their nuclei & & + & \\
\hline
\end{tabular}

Table (5): Summary of Microscopical examination of liver of rats fed AFF or plus HPAO.

\begin{tabular}{|l|c|c|}
\hline Organ tissues disorder & AF & $+\mathrm{HP}$ \\
\hline Granularity of the cytoplasm of hepatocytes. & F & AO \\
\hline Cytoplasmic vacuolization of hepatocytes. & + & \\
\hline Kypffer cells activation. & + & + \\
\hline Vacuolization of hepatocytes. & + & \\
\hline Congestion of hepatic sinusoids. & + & \\
\hline Dilation and cungestion of hepayoportal vrssels & + & \\
\hline Hepatocytes necrosis & + & \\
\hline Hepatocytes active nuclai & + & \\
\hline Epithelial vasicular lining bile duct & + & \\
\hline
\end{tabular}




\begin{tabular}{|l|l|l|}
\hline Portal infiltration & + & \\
\hline Congestion of central vein. & + & \\
\hline Slight granularity of the cytoplasm of hepatocytes. & + & \\
\hline Presence of small vacuoles in the cytoplasm of hepatocytes. & + & \\
\hline $\begin{array}{l}\text { Presence of smallvacuoles in the cytoplasm of sporadic } \\
\text { hepatocytes. }\end{array}$ & + & \\
\hline
\end{tabular}

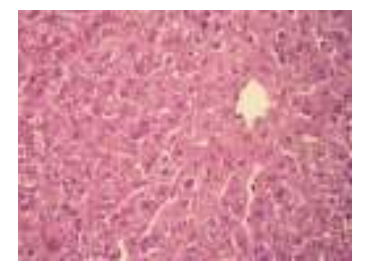

Fig (1): Liver of normal rats
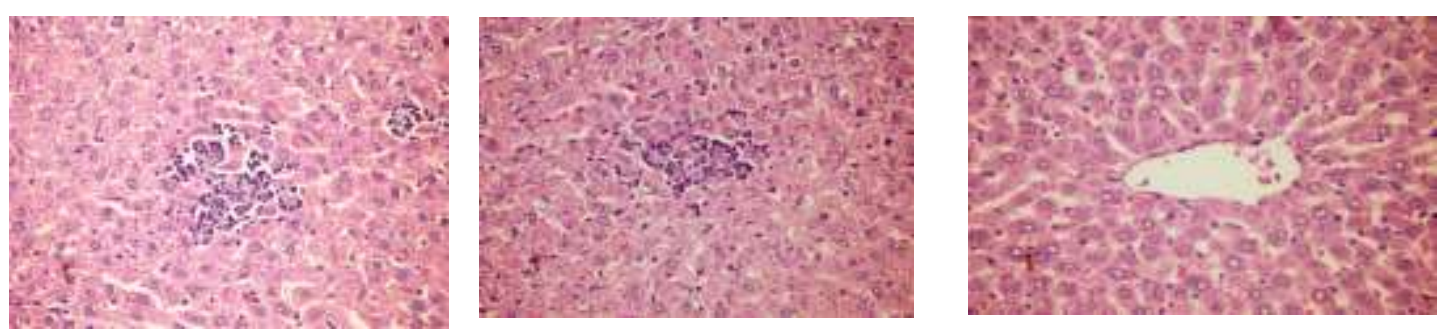

Fig (2): Rat liver fed high fat.
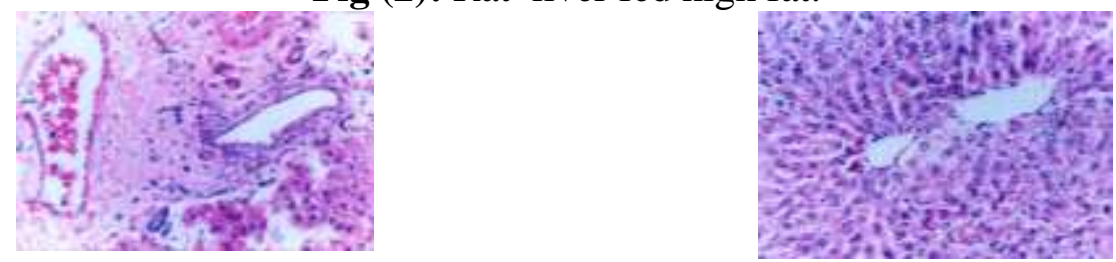

Fig (3): Rat liver fed TCC Toxin control and TCC+grape leaves extract ( $\mathrm{H}$ and $\mathrm{E} \times$ 200).
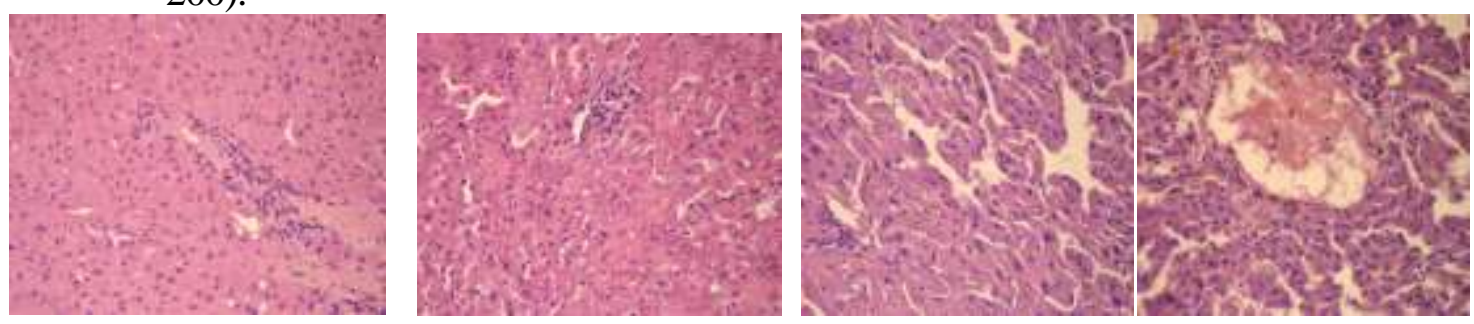

Fig. (4): Liver of rat treated with TPN and Parsley and Green Tea or lasixe
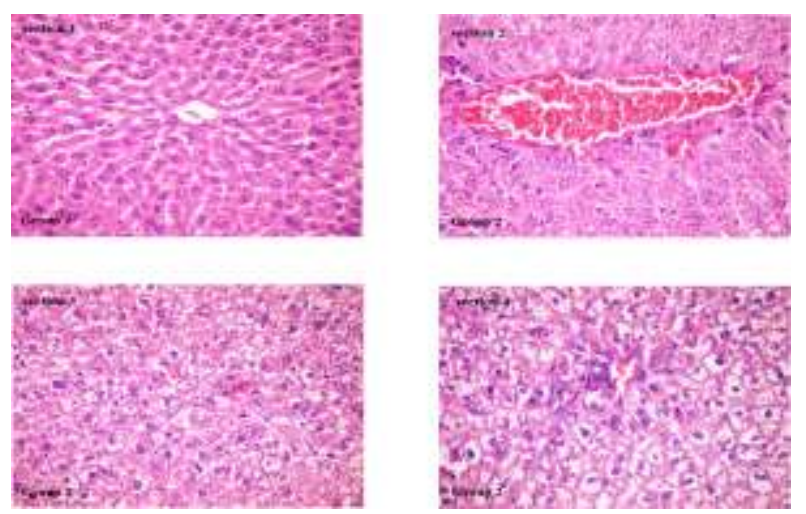

Figure (5) liver of rat fed aflatoxin or + high protien AO formula. 
The microscopical examination of liver of rat with diet contaminated of mucotoxin showed congestion of central vein, granularity of the cytoplasm of hepatocytes and cytoplasmic vacuolization of hepatocytes. However, congestion of central vein, slight granularity of the cytoplasm of hepatocytes, and presence of small vacuoles in the cytoplasm of hepatocytes was photographed in some section, whereas, other sections from the same group showed kupffer cells activation and presence of small vacuoles in the cytoplasm of sporadic hepatocytes. Moreover, cytoplasmic vacuolization of hepatocytes (small vacuoles in the cytoplasm of hepatocytes) was noticed in Figure 5. Therefor, the hormonal imbalance and oxidative stress widely exposed biological system to several degenerative disorders. Moreover, and beyond liver relay to hormonal imbalance, Stewart et al. (1999) have stated that glucocorticoids play an important role in determining body fat distribution, but circulating cortisol concentrations are reported to be normal in obese patients. The recent studies show enhanced conversion of inactive cortisone to active cortisol, which is a crucial factor in the pathogenesis of central obesity. This reduction in activity raises new questions as to the primary role in the pathogenesis of insulin resistance and central obesity.

In general conclusion, feeding pattern should be developed to help protecting human liver, especially in poor areas allovers the world. Very simple foods or even food wastes is considered hepatoprotective agents as seen in this study. The hormonal oxidative balance has to be further investigated in order to produce such important food help in the protection of liver worldwide.

\section{REFRENCES}

Abo-Zeid, FKS; NM Mahmoud; NA Ebostany and AIS Ahmed (2008): Antioxidant consumption may prevent some hepatic carcinoma. Egy. J. Biomed. Sci. 26, March, 158-169.

Ahmed, A. I. S.; F El-Deeb*, A. A. Hammad And Kh. M. Nematalla (2006): Rp-Hplc Evaluation For Some Insulin Interactions. J Agric Sci Mansoura Univ, 31, 12, 7787-98

Ahmed, A.I.S.; Mh Esaied And Ghada M Youssef (2001): Simple SFC Technique For Sterol Estimation. 50-60. Comibassal Food Quality Con. Alex, June Egypt.

Ahmed, A.I.S; Thabet, Ha And Shallan, Ma (1999b): “ On The Interaction Of Fat And Food Metabolites With Insulin.” Cont. Med. Edu. Conf. Ain Shams Univ. Cairo.

Ahmed, Ali I. S. Fathia, K S Abo Zeid And Adel A. El-Bagoury (2003a): "Hormonal Oxidative Balance Of Modified Diets And Uncontrollable Cholesterol”. Egy. J of Biomedical Sciences. Vol 13, 106-115.

Ahmed, M. Gaafar*; Fadal, M. El-Deeb** and Gada, M. Yoyssef (2010): Grape Leaves (Vitis vinifera L.) Antioxidant Activity on $\mathrm{CCl}_{4}$ Induced Rat Liver Injury. Az. J. Pharm. Sci. 42, Sept. 2010, 206-218.

Ahmed; AIS; Fathia K Abo-Zeid; Neven M Mahmoud and Fadle A El-Deeb*. (2008): Complication of total parentral nutrition (tpn) 1. a rat's main blood chemistry responses. J. Biol. Pham. Sci. Vol. 7, No. 1 July, 2009, 11-20.

Araya, A; Shannon L Kelleher, Miguel A Arredondo, Walter Sierralta, María Teresa Vial, Ricardo Uauy, and Bo Lönnerdal, (2005): Effects of chronic copper exposure during early life in rhesus monkeys Am J Clin Nutr May 2005 81: 5 1065-1071. 
Bayomey, A.M.*; Sayed Ahmed, E.F.* and Abou-Sebaa, Sherin Sayed (2010): The Hypolipidemic Properties of Doum Palm Fruit and Its Aqueous Extracts. Egy. Nutr. Health, 5, 1.

Bergmeyer, H. U. and Harder, M. (1986): A colorimetric method of the determination of serum glutamic oxaloacetic and glutamic pyruvic transaminase Clin. Biochem. 24: 481 .

Blocker, DE and W Thenen, (1987): Intestinal absorption, liver uptake, and excretion of $3 \mathrm{H}$-folic acid in folic acid-deficient, alcohol-consuming nonhuman primates. Am J Clin Nutr September 1987 46: 3 503-10

Cardiovascular disease risk: Ebe D'Adamo, Veronika Northrup, Ram Weiss, Nicola Santoro, Bridget Pierpont, Mary Savoye, Grace O'Malley, and Sonia Caprio, (2010): Ethnic differences in lipoprotein subclasses in obese adolescents: importance of liver and intraabdominal fat accretion Am J Clin Nutr September 2010 92: 3 500-508; First published online June 23, 2010. doi:10.3945/ajen.2010.29270

Castellanos, H and Guillermo Arroyave (1961): Role of the Adrenal Cortical System in the Response of Children to Severe Protein Malnutrition. Am J Clin Nutr March 1961 9: 2 186-195.

D'Adamo, Ebe; Veronika Northrup, Ram Weiss, Nicola Santoro, Bridget Pierpont, Mary Savoye, Grace O'Malley, and Sonia Caprio, (2010): Ethnic differences in lipoprotein subclasses in obese adolescents: importance of liver and intraabdominal fat accretion Am J Clin Nutr September 2010 92: 3 500-508.

De Pirro, R; Aldo Bertoli; Angelo Fusco; Ivano Testa; Aldo V. Greco and Renato Lauro (1980): Effect of Dexamethasone and Cortisone on Insulin Receptors in Normal Human Male*The Journal of Clinical Endocrinology \& Metabolism. September 1, 1980 vol. 51 no. 3503-507.

FAO/WHO Expert committee (1974): Toxicological evaluation of some food additives. Food and Agriculture Organization of the United Nations World Health Organization, Rome, 1975.

Fathia Abozied \& Ais Ahmed (2002): "Health Aspect Of Some Heavy Metals In Food Contamination". Assiut Univ. 3rd Intr. Conf. Oct. 2002.

Frankel, S. and Reitman, S. (1963): Clinical Laboratory's Method. The C.V. Mosby Company. 1102.

Gasteyger, C; Thomas M.; Larsen, F. V., and Arne A, (2008): Effect of a dietary-induced weight loss on liver enzymes in obese subjects Am J Clin Nutr May 2008 87: 5 $1141-1147$

Giovanni Musso, G; Maurizio Cassader, Franco De Michieli, Francesca Saba, Simona Bo, and Roberto Gambino, (2011): Effect of lectin-like oxidized LDL receptor1 polymorphism on liver disease, glucose homeostasis, and postprandial lipoprotein metabolism in nonalcoholic steatohepatitis Am J Clin Nutr October 2011 94: 4 1033-1042.

Guerrerio,AL; Ryan M Colvin, Amy K Schwartz, Jean P Molleston, Karen F Murray, AnnaMae Diehl, Parvathi Mohan, Jeffrey B Schwimmer, Joel E Lavine, Michael S Torbenson, and Ann O Scheimann, (2012): Choline intake in a large cohort of patients with nonalcoholic fatty liver disease Am J Clin Nutr April 2012 95: 4 892-900. 
Hausberger, Franz X. (1958): Influence of insulin and cortisone on hepatic and adipose tissue metabolism of rats ${ }^{1}$ endocrinology July 1, 1958 vol. 63 no. 1 14-19.

Korpela, H; J Kumpulainen, $P$ V Luoma, A J Arranto, and E A Sotaniemi, (1985): Decreased serum selenium in alcoholics as related to liver structure and function. Am J Clin Nutr July 1985 42: 1 147-51

Marklund, S. and Marklund, G., (1974): SOD activity assay by the method of pyrogallol. Eur. J. Gerontol. 17, 429-437.

Ménard, M C (1983): Synergistic Effects of Insulin and Thyroxine on the Differentiation and Proliferation of Epithelial cells of suckling mouse small intestine. Biol Neonate; 44:177-184

Moron, M.S., Depierre, J.W. and Mannervik, B. (1979): Levels of glutathione, glutathione reductase and glutathione - s-transferase activities in rat lung and liver. Biochem. Biophys. Acta 582, 67-78.

Munnich, A; J Marie; G Reach; S Vaulont; M P Simon and A Kahn (1984): In vivo hormonal control of L-type pyruvate kinase gene expression. Effects of glucagon, cyclic AMP, insulin, cortisone, and thyroid hormones on the dietary induction of mRNAs in the liver. August 25, 1984 The Journal of Biological Chemistry, 259, 10228-10231.

Musso, G; Roberto Gambino, Franco De Michieli, Giampaolo Biroli, Alberto Premoli, Gianfranco Pagano, Simona Bo, Marilena Durazzo, and Maurizio Cassader, (2007): Nitrosative stress predicts the presence and severity of nonalcoholic fatty liver at different stages of the development of insulin resistance and metabolic syndrome: possible role of vitamin A intake Am J Clin Nutr September 2007 86: 3 661-671

Orhan, D.D., Orhan, N. and Ergun, F. (2007): Hepatoprotective effect of Vitis vinifera L. leaves on carbon tetrachloride-induced acute liver damage in rats. The Journal of Ethnopharmacology 12, 145-151.

Purohit, V Manal F Abdelmalek, Shirish Barve, Norlin J Benevenga, Charles H Halsted, Neil Kaplowitz, Kusum K Kharbanda, Qi-Ying Liu, Shelly C Lu, Craig J McClain, Christine Swanson, and Samir Zakhari, (2007): Role of Sadenosylmethionine, folate, and betaine in the treatment of alcoholic liver disease: summary of a symposium Am J Clin Nutr July 2007 86: 1 14-24

Sinha, A. K. (1972): Colorimetric assay of catalase. Anal. Biochem. 47 (2), 389-404.

Snedecor, GW and Cochran, WG (1967): Statistical methods. $6^{\text {th }}$ ed. Iowa State Univ., Press Ames, Iowa USA.

Stewart $^{2}$, PM Abigail Boulton, Sudhesh Kumar, Penny M. S. Clark and Cedric H. L. Shackleton (1999): Cortisol Metabolism in Human Obesity: Impaired Cortisone $\rightarrow$ Cortisol Conversion in Subjects with Central Adiposity ${ }^{1}$ The Journal of Clinical Endocrinology \& Metabolism March 1, 1999 vol. 84 no. 31022-1027.

Stull CL, Rodiek AV. (1988): Responses of blood glucose, insulin and cortisol concentrations to common equine diets. J Nutr. 1988 Feb;118(2):206-13.

Zivkovic, Angela M; J Bruce German, and Arun J Sanyal, (2007): Comparative review of diets for the metabolic syndrome: implications for nonalcoholic fatty liver disease Am J Clin Nutr August 2007 86: 2 285-300. 
علاقة الآنماط الغذئية و التوازن الهورموني الاكسيدي بالعمر الافتراضي للكبد في الفئران

علي ابراهيم احمد - عبد المنعم سامي حشيش - سلوي جبل - نيفين الورداني

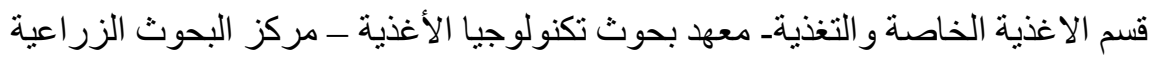

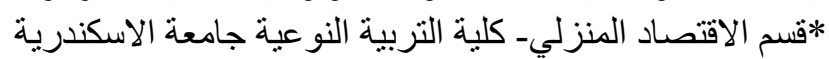

أجريت هذه الدراسة بهدف الحد من ظاهرة تلف الكبد الناجم من سوء التغذية. ولقد تم الربط في هذا البحث بين تلوث

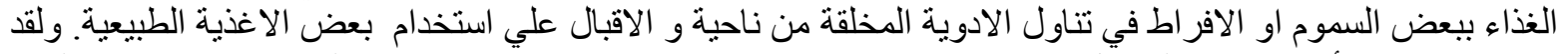

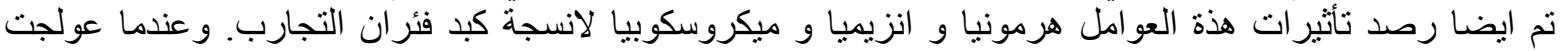

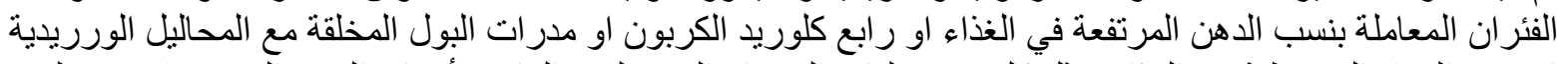

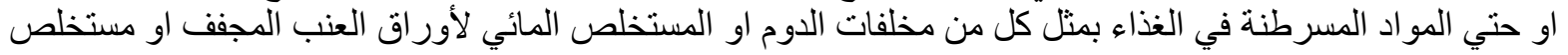

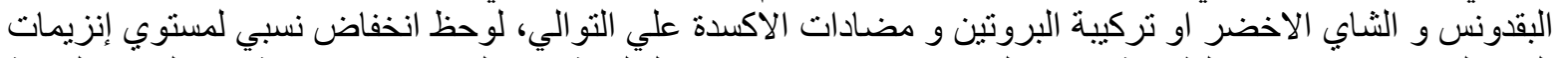

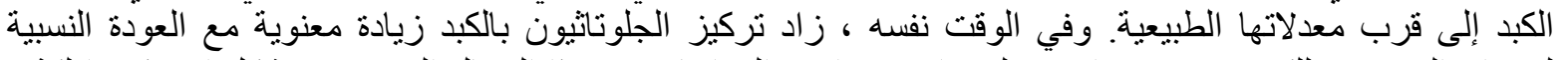

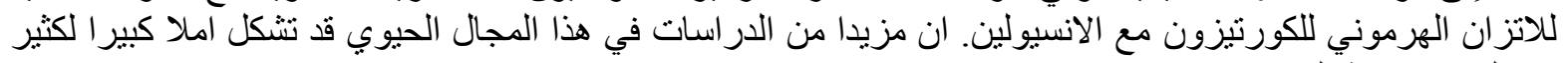

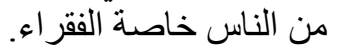

